\title{
PENGARUH KOMPETENSI DAN KOMUNIKASI TERHADAP KINERJA PEGAWAI PT. BUKIT ASAM (PERSERO), TBK UNIT DERMAGA KERTAPATI PALEMBANG
}

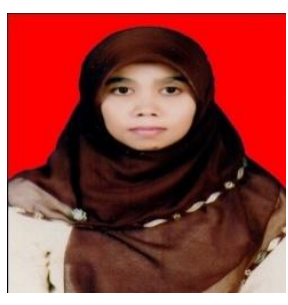

\author{
Oleh : \\ Nisa' Ulul Mafra \\ Dosen Fakultas Ekonomi Universitas PGRI Palembang \\ Email : nisaulul@yahoo.co.id
}

\begin{abstract}
Abstrak
Penelitian ini berjudul Pengaruh Kompetensi Dan Komunikasi Terhadap Kinerja Pegawai PT. Bukit Asam (Persero), Tbk Unit Dermaga Kertapati Palembang. Tujuan penelitian ini adalah: untuk mengetahui pengaruh kompetensi dan komunikasi secara bersama-sama dan secara parsial terhadap kinerja pegawai pada PT. Bukit Asam (Persero), Tbk Unit Dermaga Kertapati Palembang. Metode penelitian: penelitian ini menggunakan metode multiple regresssion model yaitu desain penelitian yang akan mengungkapkan pengaruh kolektif variabel bebas terhadap satu variabel terikat. Data yang digunakan yaitu data primer dan data skunder yang dikumpulkan melalui kuesioner. Adapun instrumen penelitian ini menggunakan proportionate stratified random sampling technique, dan jumlah sampel sebanyak 51 orang pegawai PT. Bukit Asam (Persero), Tbk Unit Dermaga Kertapati Palembang.

Hasil penelitian: kinerja pegawai PT. Bukit Asam (Persero), Tbk Unit Dermaga Kertapati Palembang dipengaruhi oleh kompetensi dan komunikasi. Hal ini dibuktikan dengan analisis dari koefisien determinasi $\left(\mathrm{r}^{2}\right)$. Pada penelitian ini nilai koefisien determinasinya sebesar 0, 292yang artinya variabel kinerja pegawai sebesar $29,2 \%$ dapat dijelaskan secara bersama-sama oleh variabel kompetensi $\left(\mathrm{X}_{1}\right)$ dan komunikasi $\left(\mathrm{X}_{2}\right)$, sedangkan sisanya $70,8 \%$ dijelaskan oleh faktor atau variabel lain yang tidak ditelliti dalam penelitian ini.
\end{abstract}

Kata kunci: Kompetensi, Komunikasi dan Kinerja Pegawai

\section{A. Latar Belakang Penelitian}

Pengembangan sumber daya manusia berbasis kompetensi dan komunikasi dilakukan agar dapat memberikan hasil sesuai dengan tujuan dan sasaran perusahaan dengan standar kinerja yang telah ditetapkan. Hal ini dikarenakan kinerja perusahaan tidak hanya ada pada level manajer puncak (top manager) saja tetapi juga harus ada pada manajer menengah (middle manager) dan manajer bawah (lower manajer) terutama para pegawai. Kinerja yang berasal dari pengertian performance. Ada pula yang memberikan pengertian performance sebagai hasil kerja atau prestasi kerja (Wibowo, 2011:7). Pencapaian kinerja yang baik perlu didukung oleh beberapa faktor, misalnya kompetensi dan komunikasi di semua level perusahaan terutama para pegawai yang lebih banyak melakukan beban kerja perusahaan.

Menurut Spencer dalam Moeheriono (2014:5) kompetensi didefinisikan sebagai karakteristik yang mendasari seseorang berkaitan dengan efektivitas kinerja individu dalam pekerjaannya atau karakteristik dasar individu yang memiliki hubungan kausal atau sebagai sebab-akibat dengan kriteria yang dijadikan acuan, efektif atau berkinerja prima atau superior di tempat kerja atau situasi tertentu. Komunikasi merupakan kegiatan berangkai sehingga menjadi proses dan karena berlangsung antar manusia (interpersonal) yang berbeda-beda dan 
bersifat unik, maka sifatnya selalu dinamis dan unik pula (Ani, 2011:142).

Hal inipun berlaku bagi PT. Bukit Asam (Persero), Tbk Unit Dermaga Kertapati Palembang yang bergerak pada bidang bongkar muat batu bara dari Tanjung Enim untuk mencapai visi dan misi perusahaan yaitu Total Productive Maintenance (TPM) yang disingkat menjadi TPM Derti. Penerapan TPM Derti dengan singkatan 5R-5S $(5 \mathrm{R}=$ ringkas, rapi, resik, rawat, rajin dan $5 \mathrm{~S}=$ seiri, seito, seiso dan shitsuke) memberikan acuan bagi semua aktivitas di PT. Bukit Asam (Persero), Tbk Unit Dermaga Kertapati Palembang yang terkait dengan Manajemen Mutu (ISO 9001:2008), Manajemen Lingkungan (ISO SML 14001:2004) dan Manajemen Keselamatan \& Kesehatan Kerja (OHSAS 18001:2007) untuk mencapai kinerja yang optimal.

Walaupun begitu, dari fenomema yang terlihat bahwa para pegawai yang telah bekerja dan mempunyai pengalaman yang cukup lama, misalnya lebih dari 20 tahun tetapi tingkat pendidikan masih ada yang setingkat sekolah dasar. Bahkan mayoritas pendidikan pegawai setingkat sekolah lanjutan atas (SLTA). Hal dikarenakan pengangkatan pegawai melalui kerja magang yang telah dilakukan selama puluhan tahun sehingga menyebabkan tidak ada keinginan untuk melanjutkan pendidikan ke jenjang yang lebih tinggi. Selain itu terkadang ada sedikit permasalahan pada komunikasi yaitu masih terjadi kurang harmonis dan agak kaku antar unit.

\section{B. Rumusan Masalah}

Berdasarkan latar belakang yang dikemukakan diatas, maka yang menjadi rumusan utama penelitian ini adalah :
1. Apakah terdapat pengaruh antara kompetensi dan komunikasi secara bersama-sama terhadap Kinerja Pegawai PT. Bukit Asam (Persero), Tbk Unit Dermaga Kertapati Palembang.

2. Apakah terdapat pengaruh antara kompetensi dan komunikasi secara parsial terhadap Kinerja Pegawai PT. Bukit Asam (Persero), Tbk Unit Dermaga Kertapati Palembang.

\section{Tujuan Penelitian}

Adapun tujuan dari penelitian ini adalah:

1. Untuk mengetahui pengaruh antara kompetensi dan komunikasi secara bersama-sama terhadap Kinerja Pegawai PT. Bukit Asam (Persero), Tbk Unit Dermaga Kertapati Palembang.

2. Untuk mengetahui pengaruh antara kompetensi dan komunikasi secara parsial terhadap Kinerja Pegawai PT. Bukit Asam (Persero), Tbk Unit Dermaga Kertapati Palembang.

\section{Manfaat Penelitian}

Dengan dilaksanakan penelitian ini, diharapkan dapat memberi manfaat antara lain:

\section{Manfaat Teoritis.}

Penelitian ini diharapkan dapat memperluas wawasan terhadap ilmu pengetahuan terutama dalam bidang manajemen Sumber daya manusia, khususnya dalam kajian yang berhubungan dengan kompetensi, komunikasi dan kinerja pegawai. Selain itu, penelitian ini diharapkan dapat bermanfaat bagi penelitian lain. 


\section{Manfaat Praktis}

Dari aspek praktis kegunaan penelitian ini sebagai masukan kepada Manajemen PT. Bukit Asam (Persero), Tbk Unit Dermaga Kertapati Palembang untuk mengetahui keterlibatan pegawai melalui kompetensi, komunikasi yang baik dan kinerja pegawai untuk mencapai Total Productive Maintenance (TPM).

\section{E. Tinjauan Pustaka}

\section{Hasil Penelitian Terdahulu}

Hasil penelitian terdahulu yang telah dilakukan oleh Ierhasy dkk (2014) dengan menggunakan sampel sebanyak 99 orang menunjukkan bahwa komunikasi dan kompetensi kerja berpengaruh positif dan signifikan terhadap kinerja karyawan PT. Perusahaan Gas Negara (Persero) Tbk SBU III Medan. Berdasarkan koefisien determinasi $\left(\mathrm{R}^{2}\right)$ pengaruh antara variabel komunikasi (X1) Kompetensi (X2) terhadap variabel kinerja karyawan (Y) memiliki hubungan yang erat. Nilai Adjusted $R$ Square $52,9 \%$ kinerja karyawan dapat di jelaskan oleh variabel bebas (komunikasi dan variabel Kompetensi). Sedangkan sisanya $47,1 \%$ dapat dijelaskan oleh faktor-faktor lain yang diteliti dalam penelitian ini seperti gaya kepemimpinan, disiplin kerja, dan lain sebagainya. Uji serempak dan uji parsial menunjukkan bahwa komunikasi dan kompetensi kerja masing-masing berpengaruh positif dan signifikan terhadap kinerja karyawan pada PT. Perusahaan Gas Negara (Persero) Tbk SBU III Medan. Tetapi dengan adanya pengawasan sebagai variable moderating komunikasi tidak signifikan terhadap kinerja. Kompetensi kerja adalah variabel yang paling dominan berpengaruh terhadap kinerja pegawai pada PT.
Perusahaan Gas Negara (Persero) Tbk SBU III Medan.

\section{Landasan Teori}

a. Kompetensi

\section{1). Definisi Kompetensi}

Dharma (2012: 101) mendefinisikan kompetensi sebagai apa yang dibawa seseorang dalam pekerjaannya dalam bentuk, jenis dan tingkatan yang berbeda. Atribut tertentu itu (pengetahuan, keahlian dan kepiawaian) yang dibutuhkan untuk melaksanakan berbagai tugas yang berhubungan dengan suatu pekerjaan.

McClelland dalam Rivai dan Sagala (2011:299) mengemukakan kompetensi sebagai karakteristik yang mendasar yang dimiliki seseorang yang berpengaruh langsung terhadap, atau dapat memprediksikan kinerja yang sangat baik.

Dari beberapa definisi di atas dapat disimpulkan bahwa kompetensi merupakan karakteristik dasar yang dimiliki individu yang dibutuhkan untuk melaksanakan pekerjaan sesuai dengan tujuan perusahaan sehingga dapat memprediksi kinerja.

\section{2) Karakteristik Kompetensi}

Moeheriono (2014:14) berpendapat bahwa setiap individu seseorang terdapat beberapa karakteristik kompetensi dasar yang terdiri atas berikut ini:

1) Watak (traits), yaitu yang membuat seseorang mempunyai sikap perilaku atau bagaimanakah orang tersebut merespon sesuatu dengan cara tertentu.

2) Motif (motive), yaitu sesuatu yang diinginkan seseorang atau secara konsisten dipikirkan dan diinginkan yang mengakibatkan suatu tindakan atau dasar dari dalam yang bersangkutan untuk melakukan suatu tindakan. 
3) Bawaan (Self-concept) adalah sikap dan nilai-nilai yang dimiliki seseorang.

4) Pengetahuan (knowledge), yaitu informasi yang dimiliki seseorang pada bidang tertentu atau pada area tertentu.

5) Keterampilan atau Keahlian (Skill), yaitu kemampuan untuk melaksanakan tugas tertentu baik secara fisik maupun mental.

\section{3) Tujuan dan Sasaran Analisis Kompetensi}

Analisis kompetensi harus dirancang dengan sebaik-baiknya karena akan dapat memberikan informasi yang lebih rinci dan akurat perihal suatu pekerjaan pegawai. Adapun tujuan dan sasaran analisis kompetensi tersebut (Moeheriono, 2014:12) adalah sebagai berikut:

1) Menjamin pelaksanaan sistem peronalia yang digunakan benar-benar berfokus dan sangat produktif.

2) Terciptanya perekat untuk membentuk suatu sistem personalia yang terpadu dan terarah.

\section{b. Komunikasi}

\section{1) Definisi Komunikasi}

Widjaja (2010:1) mengatakan bahwa komunikasi adalah suatu kontak antar dan antara manusia baik individu maupun kelompok dalam kehidupan sehari-hari, disadari atau tidak komunikasi adalah bagian dari kehidupan itu sendiri sejak manusia dilahirkan sudah berkomunikasi dengan lingkungannya.

Muhammad (2011:7), mendefinisikan komunikasi sebagai pertukaran pesan verbal maupun nonverbal antara si pengirim dengan si penerima pesan untuk mengubah tingkah laku.

Dari beberapa definisi di atas dapat disimpulkan bahwa komunikasi merupakan interaksi yang dilakukan seseorang kepada orang lain yang merupakan kegiatan berangkai sehingga menjadi proses dan karena berlangsung antar manusia (interpersonal) yang berbeda- beda dan bersifat unik.

\section{2) Desain Komunikasi}

Arah komunikasi dalam organisasi dapat dibedakan menjadi 4 (Rivai dan Sagala,2011: 809), yaitu:

1) Komunikasi Ke bawah,

Adalah komunikasi yang mengalir dari tingkat atas ke tingkat bawah dalam sebuah organisasi dan mencakup kebijakan pimpinan, instruksi dan memo resmi;

2) Komunikasi Ke atas,

Adalah komunikasi yang mengalir dari tingkat bawah ke tingkat atas sebuah organisasi, dan mencakup kotak saran, pertemuan kelompok, dan prosedur keluhan;

3) Komunikasi Horizontal,

Adalah komunikasi yang mengalir melintasi berbagai fungsi dalam organisasi. Bentuk komunikasi ini diperlukan untuk mengkoordinasi dan mengintegrasikan berbagai fungsi organisasi;

4) Komunikasi Diagonal,

Adalah komunikasi silang melintasi fungsi dan tingkat dalam organisasi. Hal ini penting dalam situasi di mana anggota tidak dapat berkomunikasi lewat saluran ke atas, ke bawah, ataupun horisontal.

\section{3) Fungsi Komunikasi}

Fungsi komunikasi sangat berkaitan satu dengan sama lain meskipun terdapat suatu fungsi yang dominan yang terbagi atas 4 bagian (Fajar, 2009:10) yaitu: 
(a) Komunikasi Sosial

Komunikasi sosial sangat penting untuk membangun diri kita. Orang yang tidak pernah berkounikasi dengan manusia bisa dibuktikan akan tersesat karena tidak dapat menata dirinya dalam satu lingkungan.

(b) Komunikasi Ekspresif

Komunikasi yang menjadi alat untk menyampaikan perasaan kita. Perasaan tersebut dapat diungkapkan melalui musik/ lukisan/tarian.

(c) Komunikasi Ritual

Komunikasi ritual biasanya dilakukan secara kolektif seperti melakukan upacara-upacara berlainan sepanjang tahun dan sepanjang hidup yang disebut antropologis.

(d) Komunikasi Instrumental

Komunikasi yang sebagai instrumen untuk mencapai tujuan-tujuan pribadi dan pekerjaan, baik jangka pendek maupun jangka panjang.

\section{c. Kinerja Pegawai}

\section{1) Definisi Kinerja Pegawai}

Sinambela (2012:5) mengemukakan bahwa kinerja pegawai didefinisikan sebagai kemampuan pegawai dalam melakukan sesuatu keahlian tertentu. Kinerja pegawai sangatlah perlu, sebab dengan kinerja ini akan diketahui seberapa jauh kemampuan pegawai dalam melaksanakan tugas yang dibebankan kepadanya.

Wibowo (2011:47) berpendapat kinerja pegawai merupakan kegiatan pengelolaan sumber daya organisasi untuk mencapai tujuan organisasi, Tujuan adalah tentang arah secara umum, sifatnya luas, tanpa batasan waktu dan tidak berkaitan dengan prestasi tertentu dalam jangka waktu tertentu.
Dari beberapa definisi di atas dapat disimpulkan bahwa kinerja pegawai merupakan tolok ukur keberhasilan pencapaian pelaksanaan suatu program kebijakan untuk mencapai tujuan perusahaan.

\section{2) Ukuran indikator kinerja}

Pada umumnya indikator kinerja dapat dikelompokkan ke dalam 6 (enam) kategori (Moeheriono, 2014: 114) berikut ini:

(a) Efektif

Mengukur derajat kesesuaian output yang dihasilkan dalam mencapai sesuatu yang diinginkan.

(b) Efisien

Mengukur kesesuaian proses menghasilkan output dengan menggunakan biaya serendah mungkin.

(c) Kualitas

Mengukur derajat kesesuaian antara kualitas produk atau jasa yang dihasilkan dengan kebutuhan dan harapan konsumen.

(c) Ketepatan waktu

Mengukur apakah pekerjaan yang diselesaikan secara benar dan tepat waktu.

(d) Produktivitas

Mengukur tingkat produktivitas suatu perusahaan.

(e) Keselamatan

Mengukur kesehatan perusahaan secara keseluruhan serta lingkungan kerja para pegawainya ditinjau dari aspek keselamatan.

\section{F. Kerangka Pemikiran}

Kerangka pemikiran merupakan suatu model konseptual dan instrument penelitian yang aman penting serta strategis dalam kedudukannya di dalam 
keseluruhan kegiatan penelitian, tentang bagaimana teori berhubungan dengan berbagai faktor yang telah diidentifikasi sebagai masalah riset (Arikunto, 2010: 134). Pada bagian ini secara teoritis dijelaskan hubungan variabel terikat dan variabel bebas, sebagai berikut:

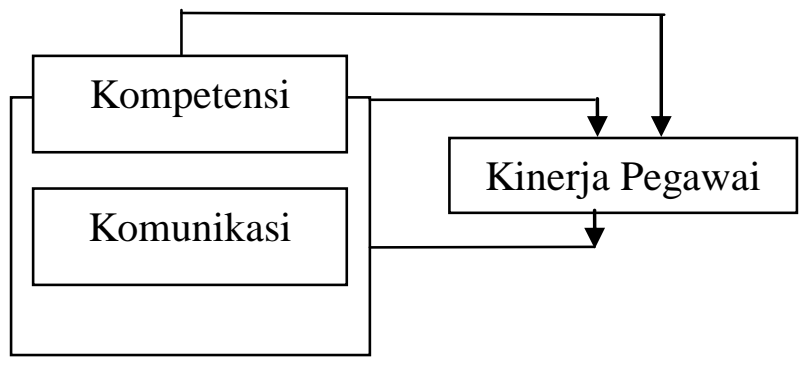

\section{Gambar 1 Kerangka Pemikiran}

Dari gambar kerangka berfikir diatas, dapat dijelaskan bahwa variabel bebas yaitu kompetensi $\left(\mathrm{X}_{1}\right)$ dan komunikasi $\left(\mathrm{X}_{2}\right)$ dan variabel terikat yaitu kinerja pegawai (Y), baik secara bersamasama maupun secara parsial akan berpengaruh. Maksudnya apabila setiap pegawai memiliki kompetensi sesuai kebutuhan dan setiap pegawai mampun berkomunikasi dengan baik pada setiap level maka pegawai tersebut akan mudah untuk meningkatkan kinerjanya. Sebaliknya jika kompetensi pegawai tidak sesuai kebutuhan dan kemampuan berkomunkasi pegawai rendah maka pegawai akan sulit untuk meningkatkan kinerjanya dengan baik.

\section{G. Hipotesis Penelitian}

Hipotesis dalam ini penelitian ini adalah sebagai berikut :

1. Terdapat pengaruh signifikan antara kompetensi dan komunikasi secara bersama-sama terhadap Kinerja Pegawai PT. Bukit Asam (Persero), Tbk Unit Dermaga Kertapati Palembang.
2. Terdapat pengaruh signifikan antara kompetensi dan komunikasi secara parsial terhadap Kinerja Pegawai PT. Bukit Asam (Persero), Tbk Unit Dermaga Kertapati Palembang.

\section{H. Prosedur Penelitian}

1. Objek Penelitian

Objek penelitian adalah Perusahaan sektor pertambangan batu bara yaitu PT. Bukit Asam (Persero), Tbk Unit Dermaga Kertapati Palembang.

\section{Metode Penelitian}

Desain penelitian yang akan digunakan adalah multiple regression model, yaitu desain penelitian yang akan mengungkap pengaruh kolektif variabel bebas terhadap satu variabel terikat. Penggunaan desain penelitian untuk membuktikan hipotesis yang telah disusun.

\section{Populasi dan Sampel \\ a. Populasi}

Sugiyono (2013: 81), populasi adalah wilayah generalisasi yang terdiri atas objek atau subjek yang mempunyai kualitas dan karakteristik tertentu yang ditetapkan oleh peneliti untuk dipelajari dan kemudian ditarik kesimpulannya. Populasi dalam penelitian ini adalah pegawai PT. Bukit Asam (Persero), Tbk Unit Dermaga Kertapati Palembang yang berjumlah 101 orang.

\section{b. Sampel}

Menurut Sugiyono (2013: 83), sampel adalah bagian dari jumlah dan karakteristik yang dimiliki oleh populasi. Sampel dalam penelitian ini adalah sebagian dari pegawai PT. Bukit Asam (Persero), Tbk Unit Dermaga Kertapati Palembang.

Penentuan sampel dalam penelitian ini menggunakan teknik Proportionate 
Stratified Random Sampling, teknik ini digunakan bila populasi mempunyai anggota/ unsur yang tidak homogen dan berstrata secara proporsional. Suatu organisasi yang mempunyai pegawai dari latar belakang pendidikan yang berstrata, maka populasi pegawai tersebut berstrata (Sugiyono, 2013: 87).

Teknik pengambilan sampel menggunakan rumus Slovin.

$$
\begin{aligned}
& \mathrm{n}=\frac{N}{1+\left(N \cdot e^{2}\right)} \\
& \mathrm{n}=\frac{N}{1+\left(N . e^{2}\right)}=\frac{101}{1+\left(101.0,1^{2}\right)}=\frac{101}{2.01}=
\end{aligned}
$$

50,24 orang pegawai

\begin{tabular}{l}
\multicolumn{2}{c}{ Berdasarkan pendapatan } & diatas, \\
peneliti mengambil sampel dalam \\
penelitian ini adalah sebanyak 51 orang \\
pegawai.
\end{tabular}

\section{Tabel 1}

Jumlah Populasi Penelitian

\begin{tabular}{|l|l|l|l|l|}
\hline No & Pendidikan & $\begin{array}{l}\text { Jumlah } \\
\text { Pegawai } \\
\text { (Orang) }\end{array}$ & $\begin{array}{l}\text { Proporsional } \\
\text { (orang) }\end{array}$ & $\begin{array}{l}\text { Jumlah } \\
\text { Responden } \\
\text { (Orang) }\end{array}$ \\
\hline 1. & Sekolah Dasar (SD) & 7 & $(7 / 101) \times 51$ & 4 \\
\hline 2. & SLTP & 9 & $(9 / 101) \times 51$ & 5 \\
\hline 3. & SLTA & 52 & $(52 / 101) \times 51$ & 25 \\
\hline 4. & Diploma 3 $\left(\mathrm{D}_{3}\right)$ & 6 & $(6 / 101) \times 51$ & 3 \\
\hline 5. & Strata 1 $\left(\mathrm{S}_{1}\right)$ & 22 & $(22 / 101) \times 51$ & 11 \\
\hline 6. & Strata 2 $\left(\mathrm{S}_{2}\right)$ & 5 & $(5 / 101) \times 51$ & 3 \\
\hline & Jumlah & 101 & & 51 \\
\hline
\end{tabular}

Sumber: Perhitungan peneliti, 2016

\section{Sumber dan Teknik Pengumpulan Data}

a. Sumber pengumpulan data yang digunakan dalam penelitian ini ada 2 (dua) yaitu data primer dan data sekunder. Data primer adalah data yang diperoleh secara langsung dari objek penelitian yaitu jawaban responden atas kuesioner yang disebarkan oleh peneliti. Dalam hal ini jawaban dari pegawai PT. Bukit Asam (Persero), Tbk Unit Dermaga Kertapati Palembang. Sedangkan data sekunder adalah dokumentasi yang menunjang penelitian, seperti data kepegawaian dan literatur (Sugiyono, 2013:223).

b. Teknik pengumpulan data yang digunakan adalah adalah: angket atau kuesioner (Questionnaires) yaitu teknik pengumpulan data yang dilakukan dengan cara memberi seperangkat pertanyaan/ pernyataan tertulis kepada responden untuk dijawabnya dan dokumentasi adalah barang-barang tertulis seperti, bukubuku, dokumen, peraturan-peraturan sebagainya (Sugiyono,2013:224).

\section{Teknik Uji Instrumen Penelitian}

Sebelum hasil instrument penelitian tersebut digunakan pada proses pengujian hipotesis, terlebih dahulu dilakukan uji instrumen yang meliputi:

\section{a. Uji Validitas dan Uji Reliabilitas}

Validitas instrumen adalah suatu instrumen yang digunakan untuk mengetahui seberapa tepat suatu alat ukur dapat melakukan fungsinya (Singgih, 2010:141). Alat ukur yang digunakan dalam pengujian validitas suatu kuesioner. Jenis korelasi yang digunakan adalah Pearson Correlation, dimana konsep ini mewakili variabel yang dibentuk apabila Pearson Correlation tiap pertanyaan/pernyataan lebih besar dari $r_{\text {table }}$ barulah dikatakan valid.

Sugiyono (2013:365) mengatakan bahwa pengukuran uji reliabilitas dilakukan dengan cara one shot atau pengukuran sekali saja. Pengukuran keandalan butir pertanyaan dengan sekali menyebarkan kuesioner pada responden, kemudian hasil skornya diukur korelasinya antar skor jawaban pada butir pertanyaan yang sama dengan fasilitas 
Cronbach Alpha $(\alpha)$. Suatu kuesioner dikatakan reliabel jika jawaban diberikan responden terhadap pertanyaan adalah konsisten dan nilai $r_{\text {hitung }}>r_{\text {tabel }}$.

\section{b. Teknik Analisis Data}

\section{Uji Asumsi Klasik}

Pengujian statistik dengan regresi linear berganda dapat dilanjutkan jika pengujian telah dibuktikan dengan pengujian asumsi klasik yang terdiri atas uji normalitas, uji multikolinearitas dan uji heterokesdatisitas.

\section{a) Uji Normalitas Data}

Singgih (2010: 210) berpendapat uji normalitas digunakan untuk mengetahui apakah dalam sebuah model regresi, nilai residu dari regresi mempunyai distribusi secara nomal atau tidak. Jika distribusi dari nilai-nilai residual tersebut tidak dapat dianggap berdistribusi normal, maka dikatakan ada masalah terhadap asumsi normalitas. Pengujian ini secara praktis dilakukan lewat pembuatan grafik Normal Probability Plot.

\section{b) Uji Heteroskedastisitas}

Singgih (2010: 210) mengemukakan uji heteroskedastisitas bertujuan untuk mengetahui apakah dalam model regresi terjadi ketidaksamaan varians dan residual pengamatan yang lain dengan dasar pengambilan keputusan. Deteksi ada tidaknya heteroskedastisitas dapat dilakukan dengan melihat ada tidaknya pola tertentu pada grafik scaterplot antara. SRESID dan ZPRED dimana sumbu $Y$ adalah residual ( $Y$ prediksi — Y sesungguhnya) yang telah distudentized dan sumbu $\mathrm{X}$ adalah $\mathrm{Y}$ yang telah diprediksi.

\section{c) Uji Multikolinieritas}

Singgih (2010: 203) juga berpendapat bahwa uji multikolinieritas bertujuan untuk menguji apakah pada model regresi ditemukan adanya korelasi antara variabel bebas. Model regresi yang baik seharusnya tidak terjadi korelasi diantara variable bebas. Toleransi mengukur variabelvariabel bebas yang terpilih dapat dijelaskan oleh variabel lainnya. Dalam uji multikolinieritas dapat dilihat dari nilai Variance Inflation Factor (VIF). Menurut Sujarweni (2015:226) batas dari nilai toleransi $>0,1$ atau nilai VIF $<10$ maka tidak terjadi multikolinieritas.

\section{Metode dan Rancangan Hipotesis}

Metode yang digunakan dalam penelitian ini adalah metode analisis kuantitatif, metode ini merupakan suatu metode analisis data yang menggunakan angka-angka agar pemecahan masalah dapat dilakukan secara pasti dengan perhitungan matematik. Adanya tahapan analisis kuantitatif yang digunakan untuk menganalisis data dalam penelitian ini adalah:

\section{a) Analisis Regresi Berganda}

Untuk mengetahui pengaruh kompetensi dan komunikasi terhadap kinerja pegawai PT.Bukit Asam (Persero), Tbk Unit Dermaga Kertapati Palembang, digunakan analisis regresi linier berganda (Sugiyono, 2013:293), dengan formulasi:

$$
\mathbf{Y}=\mathbf{a}+\mathbf{b}_{1} \mathbf{X}_{1}+\mathbf{b}_{2} \mathbf{X}_{2}+\boldsymbol{e}
$$

Dimana:

$$
\begin{array}{ll}
\mathrm{Y} & =\text { Kinerja Pegawai } \\
\mathrm{a} & =\text { Konstanta } \\
\mathrm{b}_{1}, \mathrm{~b}_{2} & =\text { Koefisien Regresi } \\
\mathrm{X}_{1} & =\text { Kompetensi } \\
\mathrm{X}_{2} & =\text { Komunikasi } \\
\mathrm{e} & =\text { Error Term }
\end{array}
$$


b) Uji Hipotesis

(1) Uji F (uji bersama-sama)

Uji $F$ digunakan untuk menguji pengaruh variabel kompetensi $\left(\mathrm{X}_{1}\right)$ dan komunikasi $\left(\mathrm{X}_{2}\right)$ secara bersama-sama terhadap kinerja pegawai (Y).

\section{(2) Uji t (uji parsial)}

Uji $t$ digunakan untuk menguji pengaruh yang signifikan antara kompetensi $\left(\mathrm{X}_{1}\right)$ atau komunikasi $\left(\mathrm{X}_{2}\right)$ secara parsial terhadap kinerja pegawai (Y).

(3) Uji Determinasi

Uji koefisien determinasi untuk mengukur kemampuan model dalam menerangkan variasi variabel dependen. Sujarweni (2015:164) mengemukakan koefisien determinasi $\left(\mathrm{R}^{2}\right)$ penelitian ini berguna untuk mengetahui seberapa besar ukuran variabel Dependen (Y) terhadap variabel independen $(\mathrm{X})$.

\section{J. HASIL PENELITIAN DAN PEMBAHASAN}

1. Hasil Penelitian

\section{a. Identifikasi Responden}

Karakteristik responden yang diperoleh antara lain tentang jenis kelamin, tingkat usia, pendidikan, dan masa kerja.

1) Identifikasi responden berdasarkan jenis kelamin

Jenis kelamin responden penelitian dapat dijelaskan pada tabel berikut:

\section{Tabel 2}

Jenis Kelamin

\begin{tabular}{|l|l|l|l|}
\hline No & $\begin{array}{l}\text { Jenis } \\
\text { Kelamin }\end{array}$ & Jumlah & Persentase \\
\hline 1 & Laki-laki & 38 & $74,51 \%$ \\
\hline 2 & Perempuan & 13 & $25,49 \%$ \\
\hline Jumlah & $\mathbf{5 1}$ & $\mathbf{1 0 0 \%}$ \\
\hline
\end{tabular}

Sumber: Data yang diolah, 2016.

Tabel diatas menunjukkan dari 51 responden mayoritas pegawai PT. Bukit Asam (Persero) Tbk, Unit Dermaga
Kertapati Palembang berdasarkan jenis kelamin yaitu jumlah laki-laki sebanyak 38 orang atau $74,51 \%$ dan jumlah perempuan 13 orang atau $25,49 \%$.

\section{2) Identifikasi responden berdasarkan tingkat usia}

Tingkat Usia responden penelitian dapat dijelaskan pada tabel berikut:

\section{Tabel 3}

Tingkat Usia

\begin{tabular}{|l|l|l|l|}
\hline No & Tingkat Usia & Jumlah & Persentase \\
\hline 1 & $20-29$ tahun & 8 & $15,69 \%$ \\
\hline 2 & $30-39$ tahun & 1 & $1,96 \%$ \\
\hline 3 & $40-49$ tahun & 8 & $15,69 \%$ \\
\hline 4 & Diatas 50 tahun & 34 & $66,66 \%$ \\
\hline Jumlah & $\mathbf{5 1}$ & $\mathbf{1 0 0 \%}$ \\
\hline
\end{tabular}

Sumber: Data yang diolah, 2016

Tabel diatas menunjukkan bahwa dari 51 responden pegawai PT. Bukit Asam (Persero) Tbk, Unit Dermaga Kertapati Palembang berdasarkan tingkat usia 20-29 tahun sebanyak 8 orang atau $15,69 \%$, tingkat usia 30-39 tahun sebanyak 1 orang atau $1,96 \%$, tingkat usia 40-49 yaitu sebanyak 8 orang atau $15,69 \%$, dan tingkat usia diatas 50 yaitu 34 orang atau $66,66 \%$.

\section{3) Identifikasi responden berdasarkan pendidikan terakhir}

Pendidikan terakhir responden penelitian dapat dijelaskan pada tabel berikut:

Tabel 4

Pendidikan Terakhir

\begin{tabular}{|l|l|l|l|}
\hline No & $\begin{array}{l}\text { Pendidikan } \\
\text { Terakhir }\end{array}$ & Jumlah & Persentase \\
\hline 1 & SD & 4 & $7,84 \%$ \\
\hline 2 & SLTP & 5 & $9,80 \%$ \\
\hline 3 & SLTA & 25 & $49,01 \%$ \\
\hline 4 & DIPLOMA 3 & 3 & $5,88 \%$ \\
\hline 5 & $\mathrm{~S}_{1}$ & 11 & $21,59 \%$ \\
\hline 6 & $\mathrm{~S}_{2}$ & 3 & $5,88 \%$ \\
\hline \multicolumn{2}{|l}{ Jumlah } & $\mathbf{5 1}$ & $\mathbf{1 0 0 \%}$ \\
\hline
\end{tabular}

Sumber: Data yang diolah, 2016 
Tabel diatas menunjukkan dari 51 responden bahwa mayoritas pegawai PT. Bukit Asam (Persero) Tbk, Unit Dermaga Kertapati Palembang berdasarkan tingkat pendidikan SD sebanyak 4 orang atau $7,84 \%$. SLTP sebanyak 5 orang atau $9,80 \%$. SLTA yaitu sebanyak 25 orang atau $49,01 \%$. D3 yaitu 3 orang atau 5,88\%. S1 sebanyak 11 orang atau $21,59 \%$ dan S2 yaitu sebanyak 3 orang atau 5,88\%.

\section{4) Identifikasi responden berdasarkan masa kerja}

Masa Kerja responden penelitian dapat dijelaskan pada tabel berikut:

\section{Tabel 5}

Masa Kerja

\begin{tabular}{|l|l|l|l|}
\hline No & Masa Kerja & Jumlah & Persentase \\
\hline 1 & $0-10$ tahun & 8 & $15,69 \%$ \\
\hline 2 & $11-20$ tahun & 3 & $5,88 \%$ \\
\hline 3 & $21-30$ tahun & 19 & $37,25 \%$ \\
\hline 4 & Diatas 30ahun & 21 & $41,18 \%$ \\
\hline Jumlah & $\mathbf{5 1}$ & $\mathbf{1 0 0 \%}$ \\
\hline
\end{tabular}

Sumber: Data yang diolah, 2016

Tabel diatas menunjukkan dari 51 responden mayoritas pegawai PT. Bukit Asam (Persero) Tbk, Unit Dermaga Kertapati Palembang berdasarkan masa kerja 0-10 tahun sebanyak 8 orang atau $15,69 \%$, masa kerja 11-20 tahun sebanyak 3 orang atau $5,88 \%$, dan masa kerja diatas 21-30 tahun sebanyak 19 orang atau $37,25 \%$ dan masa kerja diatas 30 tahun sebanyak 21 orang atau $41,18 \%$.

\section{b . Hasil Pengujian Data}

\section{1) Analisis pengujian data}

Pengujian dilakukan melalui dua tahap yaitu uji validitas dan uji reliabilitas. Pengujian tersebut diuraikan sebagai berikut:
Tabel 6 Hasil Uji Validitas dan Uji Reliabilitas

\begin{tabular}{|c|c|c|c|c|c|}
\hline Variabel & Item & $\begin{array}{l}\text { Pearson } \\
\text { Correlation }\end{array}$ & $\begin{array}{l}\mathrm{r}_{\text {tabel }} \\
\alpha=5 \%\end{array}$ & $\begin{array}{l}\text { Cronbach' } \\
\text { s Alpha }\end{array}$ & Keterangan \\
\hline \multirow{10}{*}{$\begin{array}{l}\text { Kompetensi } \\
\left(\mathrm{X}_{1}\right)\end{array}$} & 1 & 0,281 & \multirow{10}{*}{0,275} & \multirow{10}{*}{0,760} & Valid dan Reliabel \\
\hline & 2 & 0,566 & & & Valid dan Reliabel \\
\hline & 3 & 0,593 & & & Valid dan Reliabel \\
\hline & 4 & 0,608 & & & Valid dan Reliabel \\
\hline & 5 & 0,659 & & & Valid dan Reliabel \\
\hline & 6 & 0,639 & & & Valid dan Reliabel \\
\hline & 7 & 0,421 & & & Valid dan Reliabel \\
\hline & 8 & 0,730 & & & Valid dan Reliabel \\
\hline & 9 & 0,657 & & & Valid dan Reliabel \\
\hline & 10 & 0,514 & & & Valid dan Reliabel \\
\hline \multirow{8}{*}{$\begin{array}{l}\text { Komunikasi } \\
\text { (X2) }\end{array}$} & 1 & 0,407 & \multirow{8}{*}{0,275} & \multirow{8}{*}{0,751} & Valid dan Reliabel \\
\hline & 2 & 0,688 & & & Valid dan Reliabel \\
\hline & 3 & 0,658 & & & Valid dan Reliabel \\
\hline & 4 & 0,629 & & & Valid dan Reliabel \\
\hline & 5 & 0,575 & & & Valid dan Reliabel \\
\hline & 6 & 0,533 & & & Valid dan Reliabel \\
\hline & 7 & 0,655 & & & Valid dan Reliabel \\
\hline & 8 & 0,655 & & & Valid dan Reliabel \\
\hline \multirow{12}{*}{\begin{tabular}{|l} 
Kinerja \\
Pegawai (Y)
\end{tabular}} & 1 & 0,670 & \multirow{12}{*}{0,275} & \multirow{12}{*}{0,910} & Valid dan Reliabel \\
\hline & 2 & 0,548 & & & Valid dan Reliabel \\
\hline & 3 & 0,653 & & & Valid dan Reliabel \\
\hline & 4 & 0,631 & & & Valid dan Reliabel \\
\hline & 5 & 0,837 & & & Valid dan Reliabel \\
\hline & 6 & 0,804 & & & Valid dan Reliabel \\
\hline & 7 & 0,585 & & & Valid dan Reliabel \\
\hline & 8 & 0,728 & & & Valid dan Reliabel \\
\hline & 9 & 0,798 & & & Valid dan Reliabel \\
\hline & 10 & 0,764 & & & Valid dan Reliabel \\
\hline & 11 & 0,817 & & & Valid dan Reliabel \\
\hline & 12 & 0,708 & & & Valid dan Reliabel \\
\hline
\end{tabular}

Sumber: Pengolahan data, 2016

Dari Tabel 6 menunjukkan dari semua item pertanyaan/ pernyataan pada variabel kompetensi $\left(\mathrm{X}_{1}\right)$, komunikasi $\left(\mathrm{X}_{2}\right)$ dan kinerja pegawai $(\mathrm{Y})$ valid pada taraf nyata 5\% dapat dikatakan valid karena nilai $r_{\text {hitung }}>r_{\text {tabel }}$. indikator sebagai alat ukur yang valid dalam analisis selanjutnya. Pengujian reliabilitas dengan metode Cronbach's Alpha dimana nilai $\mathrm{r}_{\text {hitung diwakili oleh nilai }}$ alpha. Suatu kuesioner dikatakan reliabel jika jawaban diberikan responden terhadap pertanyaan adalah konsisten dan nilai $r_{\text {hitung }}$ $>r_{\text {tabel }}$.

\section{2) Uji Asumsi Klasik}

\section{(a) Uji Normalitas}

Pengujian ini secara praktis dilakukan lewat pembuatan grafik Normal Probability Plot, hal ini dapat dilihat pada grafik 1 di bawah ini; 
Grafik 1

Uji Normalitas

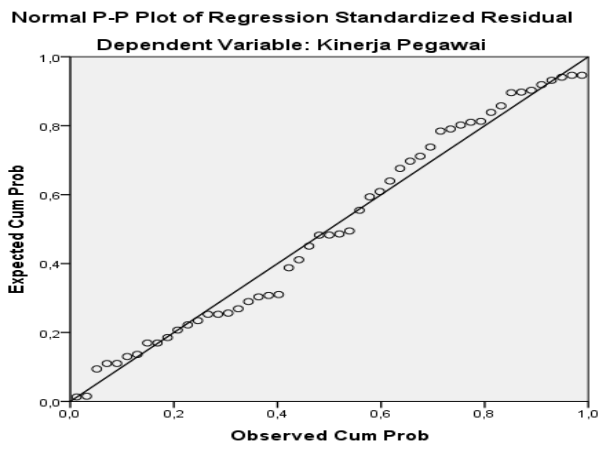

Dari grafik 1 terlihat titik-titik menyebar di sekitar garis diagonal, serta penyebarannya mengikuti arah garis diagonal, maka model regresi layak dipakai untuk prediksi kinerja dan memenuhi asumsi normalitas.

\section{(b) Uji Heteroskedastisitas}

Pada grafik 2 pola sebaran nilai prediksi variabel terikat (ZPRED) dengan residualnya (SRESID) variabel dalam deteksi heteroskedastisitas.

\section{Grafik 2}

\section{Pola sebaran nilai prediksi variabel}

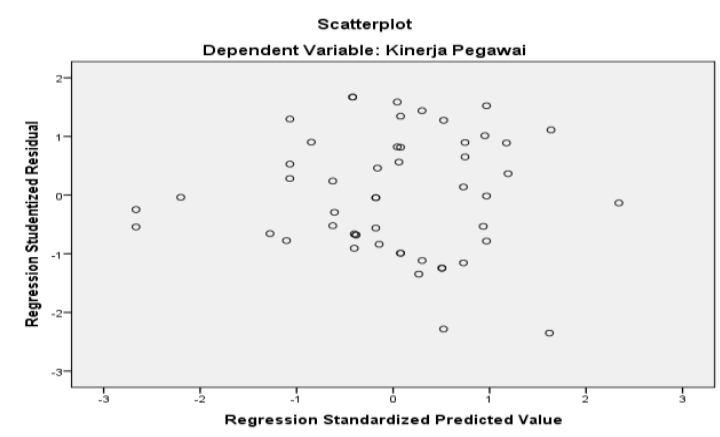

Grafik 2 Pola sebaran nilai prediksi variabel terikat (ZPRED) dengan residualnya (SRESID) variabel dalam deteksi heteroskedastisitas. Terlihat pada grafik di atas bahwa tidak ada pola tertentu seperti titik yang ada membentuk suatu pola tertentu teratur (bergelombang, yang melebar kemudian menyempit), serta titik - titik menyebar di atas dan dibawah angka 0 pada sumbu Y, maka pada model regresi tidak terjadi masalah heteroskedastisitas.

\section{(c) Uji Multikolinearitas}

Untuk mendeteksi adanya multikolinieritas dilihat dari nilai VIF (Variance Inflation Factor) dan pada masingmasing variabel bebas yang secara lengkap ditampilkan pada tabel 7 di bawah ini.

\section{Tabel 7}

VIF (Variance Inflation Factor)

\begin{tabular}{|l|l|l|}
\hline Model & \multicolumn{2}{|l|}{ Collinierity Statistics } \\
\hline 1 ( Constant) & Tolerance & VIF \\
\hline Kompetensi &, 934 & 1,071 \\
\hline Komunikasi &, 934 & 1,071 \\
\hline
\end{tabular}

a. Dependent Variable : kinerja Pegawai

Sumber: Pengolahan data,2016

Nilai VIF (Variance Inflation Factor) masing-masing variabel mempunyai nilai VIF disekitar angka 1 dan mempunyai angka tolerance mendekati 1, oleh karena itu dapat disimpulkan bahwa semua variabel bebas terhindar dari asumsi multikolinearitas.

\section{3) Teknik Analisis Data}

\section{a) Regresi Berganda}

Analisis regresi digunakan untuk melihat besaran pengaruh variabel bebas terhadap variabel terikat. Hasil pengolahan data ditunjukkan dalam tabel di bawah ini.

\section{Tabel 8}

Hasil Analisis Regresi Berganda

\begin{tabular}{|l|l|l|l|}
\hline \multirow{2}{*}{ Model } & \multicolumn{2}{|l|}{$\begin{array}{l}\text { Unstandarized } \\
\text { Coefficients }\end{array}$} & $\begin{array}{l}\text { Standarized } \\
\text { Coefficients }\end{array}$ \\
\hline & B & Std.Error & Beta \\
\hline 1 (Constanta) &, 713 &, 811 & \\
\hline Kompetensi &, 466 &, 157 &, 373 \\
\hline Komunikasi &, 387 &, 159 &, 306 \\
\hline
\end{tabular}

Defendent Variabel : Kinerja Pegawai (Y)

Sumber: Pengolahan data, 2016

Persamaan Multiple regression linier tersebut mempunyai konstanta (intercept) sebesar 0,713, hal ini berarti jika variabel kompetensi $\left(\mathrm{X}_{1}\right)$ dan komunikasi $\left(\mathrm{X}_{2}\right)$ sama dengan nol, maka kinerja pegawai $(\mathrm{Y})=$ 0,713 yang berarti setiap perubahan peningkatan satu satuan skor kompetensi dan 
komunikasi akan meningkatkan kinerja sebesar satu satuan. Sedangkan regresi sebesar 0,466 menunjukkan jika kompetensi meningkat sebesar satuan maka kinerja pegawai akan meningkat sebesar 0,466 satuan. Sebaliknya jika kompetensi menurun sebesar satuan maka kinerja pegawai akan menurun sebesar 0,466 satuan dengan asumsi variabel lain tetap. Regresi sebesar 0,387 menunjukkan jika komunikasi meningkat sebesar satu satuan akan meningkatkan kinerja pegawai sebesar 0,387 satuan. jika komunikasi menurun sebesar satu satuan akan menurunkan kinerja pegawai sebesar 0,387 satuan dengan asumsi variabel lain ceteris paribus.

b) Koefisien Determinasi $\left(\mathbf{R}^{\mathbf{2}}\right)$

Nilai koefisien determinasi $\left(\mathrm{R}^{2}\right)$ secara lengkap ditampilkan pada tabel berikut ini.

\section{Tabel 9}

Nilai Koefisien Determinasi ( $\mathbf{R}^{2}$ )

\section{Penelitian}

\begin{tabular}{|c|c|c|c|c|c|}
\hline \multicolumn{6}{|c|}{ Model Summary ${ }^{\mathrm{D}}$} \\
\hline Model & $\mathrm{R}$ & R Square & $\begin{array}{l}\text { Adjusted } \\
\text { R Square }\end{array}$ & $\begin{array}{l}\text { Std. Error } \\
\text { of the } \\
\text { Estimate }\end{array}$ & $\begin{array}{l}\text { Durbin- } \\
\text { Watson }\end{array}$ \\
\hline 1 & $\begin{array}{l}, 540 \\
a\end{array}$ & ,292 & ,262 & ,33270 & 1,466 \\
\hline
\end{tabular}

a. Predictors: (Constant), Komunikasi, Kompetensi

b. Dependent Variable: Kinerja Pegawai

Sumber: Pengolahan data,2016

Berdasarkan tabel 9 di atas diketahui

nilai koefisien korelasi (R) secara keseluruhan sebesar 0, 540 yang berarti besarnya pengaruh variabel bebas kompetensi $\left(\mathrm{X}_{1}\right)$ dan komunikasi $\left(\mathrm{X}_{2}\right)$ secara bersama-sama terhadap variabel terikat yaitu kinerja pegawai (Y) sebesar 0,540 atau $54 \%$. Sedangkan besaran sumbangan variabel bebas terhadap variabel terikat ditunjukkan dari nilai koefisien determinasi $\left(\mathrm{R}^{2}\right)$. Pada penelitian ini nilai koefisien determinasinya sebesar 0,292 yang artinya variabel kinerja pekerja sebesar 29,2 \% dapat dijelaskan secara bersama-sama oleh variabel kompetensi $\left(\mathrm{X}_{1}\right)$ dan komunikasi $\left(\mathrm{X}_{2}\right)$ sedangkan sisanya 70,8\% dijelaskan oleh faktor atau variabel lain yang tidak diteliti misal; variabel motivasi kerja, variabel kepemimpinan, variabel kepuasan kerja, dan lain-lain.

\section{4) Pengujian Hipotesis Penelitian}

\section{(a) Uji Bersama-sama (Uji F)}

Uji $F$ ini dilakukan dengan melihat probabilitas ( $p$-Value) dan atau $F_{\text {hitung }}$ terhadap $\mathrm{F}_{\text {tabel. }}$.

Tabel 10

Hasil Analisis Uji F

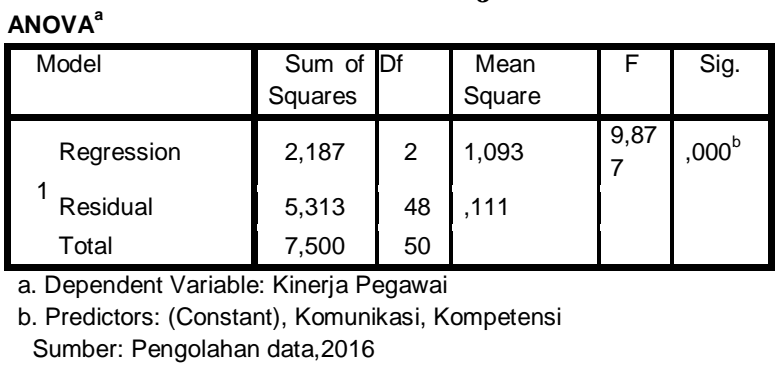

Sebagaimana keputusan uji bahwa : Ho diterima dan menolak Ha jika Sig F > 0,05 dan $F_{\text {hitung }}<$ dari $F_{\text {tabel }}$. Berdasarkan Tabel 10 diperoleh nilai $F_{\text {hitung }}$ sebesar 9,877> $F_{\text {tabel }} 3,191$ dan nilai $p$-value (Sig) sebesar $0,000<0,05$. Dengan demikian dapat disimpulkan bahwa ada pengaruh yang sangat nyata antara kompetensi $\left(\mathrm{X}_{1}\right)$ dan komunikasi $\left(\mathrm{X}_{2}\right)$ secara bersama-sama terhadap variabel kinerja pegawai (Y).

\section{(b) Uji Parsial (Uji t)}

Uji $\mathrm{t}$ ini dilakukan dengan melihat probabilitas ( $p$-Value) dan atau $t_{\text {hitung }}$ terhadap $t_{\text {tabel. }}$.

Tabel 11

Hasil Analisis Uji t

\begin{tabular}{|l|l|l|l|l|l|}
\hline Model & \multicolumn{2}{|l|}{$\begin{array}{l}\text { Unstandarized } \\
\text { Coefficients }\end{array}$} & $\begin{array}{l}\text { Standarized } \\
\text { Coefficients }\end{array}$ & $\mathrm{t}$ & Sig \\
\hline & $\mathrm{B}$ & Std.Error & Beta & & \\
\hline 1 (Constanta) &, 713 &, 811 & &, 880 &, 383 \\
\hline Kompetensi &, 466 &, 157 &, 373 & 2,967 &, 005 \\
\hline Komunikasi &, 387 &, 159 &, 306 & 2,437 &, 019 \\
\hline
\end{tabular}

Defendent Variable : Kinerja Pegawai

Sumber: Pengolahan data, 2016 
Berdasarkan hasil Uji t yang ditampilkan pada Tabel 11 untuk variabel kompetensi $\left(\mathrm{X}_{1}\right)$ dengan $\mathrm{t}_{\text {hitung }}>\mathrm{t}_{\text {tabel }}$ atau 2,967 $>2,011$ Kemudian p-Value (Sig) sebesar 0,005 < 0,05 . Dengan demikian menunjukkan bahwa pada kepercayaan sebesar $95 \%$ dapat dinyatakan kompetensi berpengaruh sangat nyata terhadap kinerja pegawai (Y).

Nilai t untuk komunikasi $\left(\mathrm{X}_{2}\right)$ sebesar $2,437>t_{\text {tabel }}$ sebesar 2,011 dan p-Value ( Sig) sebesar $0,019<0,05$. Ini menunjukkan bahwa pada tingkat kepercayaan sebesar $95 \%$ komunikasi $\left(\mathrm{X}_{2}\right)$ berpengaruh terhadap variabel kinerja pegawai (Y).

\section{Pembahasan hasil Penelitian}

a. Pengaruh Kompetensi dan

Komunikasi secara Bersama-sama terhadap Kinerja pegawai PT. Bukit Asam (Persero), Tbk Unit Dermaga Kertapati (Derti) Palembang.

Hasil uji $\mathrm{F}$ untuk variabel kompetensi dan komunikasi adalah nilai $F_{\text {hitung }}$ sebesar 9,877> $\mathrm{F}_{\text {tabel }} 3,191$ dan nilai $\mathrm{p}$-value (Sig) sebesar $0,000<0,05$. Hal ini menunjukkan terdapat pengaruh sangat nyata kedua variabel tersebut terhadap kinerja pegawai secara bersama-sama. Dengan demikian dapat disimpulkan bahwa ada pengaruh sangat signifikan antara kompetensi dan komunikasi terhadap kinerja pegawai.

Diketahui nilai koefisien korelasi (R) secara keseluruhan sebesar 0,540 yang berarti besarnya pengaruh antara kompetensi dan komunikasi terhadap kinerja pegawai sebasar 0,540 atau 54\%. Sedangkan koefisien determinasi $\left(\mathrm{R}^{2}\right)$ secara keseluruhan sebesar 0,292 atau 29,2\% artinya kinerja pegawai dapat dijelaskan oleh kompetensi dan komunikasi secara bersama-sama dan sisanya $70,8 \%$ dijelaskan oleh faktor atau variabel lain yang tidak diteliti.

Walaupun nilai koefisien determinasi $\left(\mathrm{R}^{2}\right)$ tidak terlalu tinggi tetapi pada kenyataannya setiap pekerjaan dapat diselesaikan dengan baik oleh pegawai. Hal ini karena didukung oleh faktor lain seperti masa kerja yang lama (lebih dari 20 tahun) menjadikan pegawai lebih terampil dan bukan semata-mata karena tingkat pendidikan. Selama ini pengangkatan pegawai melalui kerja magang yang telah di lakukan selama puluhan tahun sehingga menyebabkan tidak ada keinginan untuk melanjutkan pendidikan ke jenjang yang lebih tinggi. Padahal apabila pegawai memiliki kompetensi yang didukung oleh prestasi akademik dan mampu berkomunikasi yang baik, maka akan berpengaruhi terhadap pencapaian kinerja dengan lebih optimal.

Hasil penelitian ini sesuai dengan penelitian terdahulu yang telah dilakukan oleh Ierhasy dkk (2014) menunjukkan bahwa Komunikasi dan Kompetensi Kerja berpengaruh positif dan signifikan terhadap Kinerja karyawan PT. Perusahaan Gas Negara (Persero) Tbk SBU III Medan. Berdasarkan koefisien determinasi $\left(\mathrm{R}^{2}\right)$ pengaruh antara variabel komunikasi (X1) Kompetensi (X2) terhadap variabel kinerja karyawan (Y) memiliki hubungan yang erat. Kompetensi kerja adalah variabel yang paling dominan berpengaruh terhadap kinerja pegawai pada PT. Perusahaan Gas Negara (Persero) Tbk SBU III Medan.

\section{b. Pengaruh Kompetensi terhadap Kinerja Pegawai PT. Bukit Asam (Persero), Tbk Unit Dermaga Kertapati Palembang.}

Berdasarkan uji $\mathrm{t}$ untuk variabel kompetensi $\left(\mathrm{X}_{1}\right)$ diperoleh hasil $\mathrm{t}_{\text {hitung }}>\mathrm{t}_{\text {tabel }}$ atau 2,967 >2,011 Kemudian p-Value (Sig) 
sebesar $0,005<0,05$. Ini menunjukkan pada tingkat kepercayaan sebesar 95\%, kompetensi berpengaruh sangat nyata terhadap kinerja pegawai. Dengan demikian hipotesis yang menyatakan bahwa terdapat pengaruh antara kompetensi terhadap kinerja Pegawai PT. Bukit Asam (Persero), Tbk Unit Dermaga Kertapati Palembang dapat diterima. Hasil ini menggambarkan keadaan bahwa selama ini pengangkatan pegawai melalui kerja magang yang telah dilakukan selama puluhan tahun (lebih dari 10 tahun) bahkan ada yang telah bekerja lebih dari 20 tahun sebanyak 40 orang telah memberikan pengaruh yang positif terhadap kinerja pegawai menjadikan pengalaman kerja tersebut mencetak tenaga kerja terampil.

Jadi dapat disimpulkan kompetensi yang dimiliki pegawai tidak sepenuhnya didukung oleh tingkat pendidikan tetapi lebih banyak dipengaruhi oleh pengalaman kerja. Hal inilah yang menyebabkan tidak ada keinginan pegawai tersebut untuk melanjutkan pendidikan ke jenjang yang lebih tinggi. Walaupun demikian pada kenyataannya tidak menutup kemungkinan agar lebih meningkatkan kinerja pegawai perlu juga didukung dengan prestasi akademik.

\section{c. Pengaruh Komunikasi terhadap Kinerja Pegawai PT. Bukit Asam (Persero), Tbk Unit Dermaga Kertapati Palembang.}

Hasil uji t untuk komunikasi $\left(\mathrm{X}_{2}\right)$ diperoleh sebesar 2,437>tabel sebesar 2,011 dan p-Value (Sig) sebesar 0,019 < 0,05 . Ini menunjukkan bahwa pada tingkat kepercayaan sebesar 95\% komunikasi $\left(\mathrm{X}_{2}\right)$ berpengaruh terhadap kinerja pegawai. Dengan demikian hipotesis yang menyatakan bahwa terdapat pengaruh antara komunikasi terhadap kinerja Pegawai PT. Bukit Asam (Persero), Tbk
Unit Dermaga Kertapati Palembang dapat diterima. Nilai yang diperoleh sebesar $0,019<0,05$. mengambarkan keadaan yang terjadi bahwa ketika bekerja setiap pegawai tidak terlalu mementingkan berkomunikasi. Kenyataan ini membuktikan dibutuhkan kerjasama yang baik antara semua pihak terutama perusahaan sebagai mediator untuk meningkatkan komunikasi yang diharapkan nantinya dapat tertanam dengan baik yang dapat mendorong kemampuan pegawai menciptakan keterbukaan dalam proses pekerjaan dan perubahan sikap yang lebih baik.

Kinerja yang tinggi perlu didukung oleh komunikasi yang baik sehingga akan terjalinnya hubungan yang harmonis antar pegawai baik ketika berkomunikasi dalam bekerja ataupun di luar pekerjaan. Sedangkan komunikasi pegawai yang baik akan menjadi budaya dan menunjang pekerjaan sehingga tidak menimbulkan kesalahpahaman dalam penyampaian informasi.

\section{K. Kesimpulan Dan Saran \\ 1. Kesimpulan}

Berdasarkan hasil penelitian dan pembahasan dapat disimpulkan bahwa kompetensi dan komunikasi mempunyai pengaruh terhadap kinerja pegawai PT. Bukit Asam (Persero), Tbk Unit Dermaga Kertapati Palembang. Hal ini terbukti bahwa meningkat atau menurunnya kinerja pegawai sangat ditentukan oleh variabelvariabel tersebut, serta penelitian ini membuktikan hipotesis yang menyatakan bahwa:

a. Ada pengaruh antara kompetensi dan komunikasi secara bersama-sama terhadap kinerja pegawai PT. Bukit Asam (Persero), Tbk Unit Dermaga Kertapati Palembang. 
b. Ada pengaruh antara kompetensi dan komunikasi secara parsial terhadap kinerja pegawai PT. Bukit Asam (Persero), Tbk Unit Dermaga Kertapati Palembang.

\section{Saran}

Dari pembahasan dan kesimpulan maka ada beberapa saran yang dapat diberikan untuk mendukung pencapaian visi dan misi PT. Bukit Asam (Persero), Tbk Unit Dermaga Kertapati Palembang yaitu:

a. Pimpinan PT. Bukit Asam (Persero), Tbk Unit Dermaga Kertapati (Derti) Palembang hendaknya mampu membuat kebijakan dan program secara efektif dalam meningkatkan kinerja pegawai untuk mencapai Total Productive Maintenance (TPM).

b. Walaupun pengalaman kerja rata-rata pegawai tinggi, misal magang lebih dari 20 tahun sehingga memiliki kompetensi yang tinggi sesuai dengan sistem yang berlaku di perusahaan, tetapi prestasi akademik dalam hal ini adalah tingkat pendidikan juga diperlukan untuk menunjang pekerjaan yang akan berpengaruh terhadap kinerja pegawai.

c. Komunikasi pegawai PT. Bukit Asam (Persero), Tbk Unit Dermaga Kertapati Palembang harus dimulai diperbaiki agar tidak menghambat jalannya pekerjaan masing-masing bagian dengan mempererat ikatan silaturahmi terutama dengan mengadakan kegiatan sosial yang melibatkan semua pegawai.

\section{DAFTAR PUSTAKA}

Ani. 2011. Strategi Belajar Mengajar. Bandung: CV Pustaka Setia.

Arikunto, Suharsimi. 2010. Manajemen Penelitian. Jakarta: Penerbit PT Rineka Cipta.
Dharma, Surya. 2012. Manajemen Kinerja. Yogyakarta: Pustaka Pelajar

Fajar, Marheini. 2009. Ilmu Komunikasi Teori dan Praktek. Yogyakarta: Graha Ilmu.

Ierhasy, Saumanda Tazilio, Prihatin Lr dan Parapat G. 2014. Pengaruh Komunikasi dan Kompetensi Terhadap Kinerja Pegawai Dengan Pengawasan Sebagai Variabel Moderating Pada PT Perusahaan Gas Negara (Persero) Tbk SBU Distribusi Wilayah III Sumatera Bagian Utara. Jurnal Ekonomi, Vol 17, No 3.

Muhammad, Arni. 2011. Komunikasi Organisasi. Jakarta : PT. Bumi Aksara.

Moeheriono. 2014. Pengukuran Kinerja Berbasis Kompetensi. Cetakan ke-2. Jakarta: Penerbit Raja Grafindo Persada.

Rivai, Veithzal dan Ella Jauvani Sagala. 2011. Manajemen Sumber Daya Manusia untuk Perusahaan. Jakarta: Penerbit PT.Raja Grafindo Persada.

Singgih, Santoso. 2010. Statistik Parametrik Konsep dan Aplikasi Dengan SPSS. Jakarta: Penerbit PT Elex Media Komputindo Kelompok Gramedia, Anggota IKAPI.

Sinambela, Lijan Poltak, 2012, Kinerja Pegawai dan Teori Pengukuran dan Implkasi. Yogyakarta, Graha Ilmu.

Sugiyono, 2013, Metode Penelitian Manajemen, Bandung, CV. Alfabeta. Sujarweni, V. Wiratna. 2015. Metodelogi Penelitian Bisnis dan Ekonomi. Jakarta:Pustaka Baru Press.

Wibowo, 2011. Manajemen Kinerja. Jakarta: Penerbit PT Raja Grafindo Persada.

Widjaja, H A. W. 2010. Komunikasi (Komunikasi dan Humas). Cetakan ke enam. Jakarta: PT.Bumi Aksara. 